\title{
THE ASSOCIATION BETWEEN PERSONAL HYGIENE AND EGG POSITIVE RATE OF ENTEROBIUS VERMICULARIS AMONG PRIMARY SCHOOL CHILDREN
}

\author{
Ratna Muliawati, Mushidah, Siti Musyarofah \\ Study Program in Public Health, School of Health Sciences Kendal
}

\begin{abstract}
Background: Pinworm or Enterobius vermicularis is the most common type of intestinal worm infection worldwide. The prevalence of pinworm infection in primary school children is high (17-38\%). In theory, pinworm infection is related to personal hygiene, but empirical study to estimate this relationship in Indonesia is lacking. This study aimed to determine the assocciation between personal hygiene and egg positive rate of pinworm among primary school children.

Subjects and Method: This was a cross sectional study conducted in the working area of Kaliwungu community health center (puskesmas), Kendal, West Java. A total of 150 students in grades 1 to 3 at Kutoharjo 1 primary school was selected for this study. The independent variable was personal hygiene, which was measured by questionnaire. The dependent variable was the presence of pinworm worm egg, which was measured by periplaswab using the Graham Scot tape method and saturated $\mathrm{NaCl}$ floatation examination. The data were analyzed by Chi-square.

Results: Positive number of worm egg was $37.3 \%$ in the perianal and $44 \%$ in the hand nail area. Poor personal hygiene was positively associated with the presence of pinworm egg in the perianal $(\mathrm{OR}=3.60 ; 95 \% \mathrm{CI}=1.72$ to $7.55 ; \mathrm{p}=0.001)$ and hand nail $(\mathrm{OR}=2.93 ; 95 \% \mathrm{CI}=1.47$ to $5.85 ; \mathrm{p}=0.002)$. Worm egg presence in the hand nail was positively associated with the presence of worm egg in the perianal area $(\mathrm{OR}=3.39$; $95 \% \mathrm{CI}=1.70$ to $6.76 ; \mathrm{p}=0.001$ ).
\end{abstract}

Conclusion: Poor personal hygiene is positively associated with pinworm infection and the transmission process occurs through hands to mouth.

Keywords: pinworm, infection, worm egg, personal hygiene, primary school student

\section{Correspondence:}

Ratna Muliawati. Study Program in Public Health, School of Health Sciences Kendal, Central Java, Indonesia. Email: r.moelia@gmail.com. Mobile: 085721222658.

The $6^{\text {th }}$ International Conference on Public Health

Best Western Premier Hotel, Solo, Indonesia, October 23-24, 2019 | 38 https://doi.org/10.26911/the6thicph.01.15 